\title{
Student Political Participation a Head of the 2020 Simultaneous Regional Elections in Central Java
}

\author{
Nunik Retno Herawati ${ }^{1}$, Fitriyah ${ }^{2}$ \\ \{nunikretno92@gmail.com ${ }^{1}$ \} \\ Universitas Diponegoro, Indonesia ${ }^{1,2}$
}

\begin{abstract}
This study is an opinion poll to measure the level and form of student political participation ahead of the 2020 regional elections in Central Java. This study takes research subjects with the consideration that students are young voters whose numbers and potential are large enough, so that it is expected that the level of participation is high. Knowing the level of student political participation can at least be a barometer of political participation in the 2020 Pilkada Simultaneously in Central Java which will be held on December 9, 2020. This research is very important because of the concerns of some people about the level of political participation in the 2020 Pilkada Simultaneously in Java. Middle which is assumed to be low due to the Covid-19 pandemic.
\end{abstract}

Keywords: Political Participation, Concurrent Pilkada

\section{Introduction}

In modern times like today, general elections at the national government level and Pilkada at the regional government level occupy an important position because elections are an important mechanism for the sustainability of representative democracy. Elections are also an indicator of a democratic country. Elections also have broad implications, including weakening and ending authoritarian regimes [1].

Political participation in a democratic country is substantial. One of the basic reasons related to this is because one of the indicators of the quality of democracy is determined by high and low levels and how political participation is carried out. Political participation is the activity of a person or group of people to actively participate in political life, among others by electing leaders in general elections, including the simultaneous regional elections.

The Association for Elections and Democracy (Perludem) is concerned that voters who will use their voting rights will find it difficult during the Corona virus pandemic. This is based on the experience of countries holding election agendas during the pandemic experiencing a significant decline in voter participation, as a result of people who feel unsure of their safety and security when they have to participate in elections amidst the high threat of the spread of Covid-19. Amid the concerns of most community groups, the KPU has targeted the number of voter turnouts in the 2020 simultaneous regional elections nationally to be 77.5 percent.

Bawaslu is worried that public participation in the 2020 Regional Head Election (Pilkada) will decline because it was held in the middle of the Covid-19 pandemic. Participation meant public participation not only during voting day 9 December. However, it 
is also the participation of the public in supervising the Pilkada stage by stage, including before the voting day.

The high level of voter participation in the Pilkada is interesting to study even though the political behavior of the community can change and change depending on the preferences behind it. There are several approaches that can affect the high level of political participation, namely the sociological approach, the psychological approach, and the rational approach [2]. This research tries to analyze voter participation in the 2020 Pilkada in Central Java which will be held on December 9, 2020. This initial research was conducted by many survey institutions to predict the level of political participation, although the results must be re-tested through the exit poll method Pilkada later.

\section{Research Methods}

The study used an online survey technique to Diponegoro University students who had the right to vote in 21 cities / districts in Central Java at random. The online survey was conducted on June 15, 2020, the results obtained were 213 student responses who answered the questionnaire. After the reduction was carried out in accordance with the required data, 125 respondents were declared valid. Data analysis was performed in the form of a frequency table using SPSS. The following is data on the distribution of respondents based on age, gender and by area of residence.

Table 1. Respondent based Gender

\begin{tabular}{|c|c|c|c|c|}
\hline Gender & Frequency & Percent & $\begin{array}{c}\text { Valid } \\
\text { Percent }\end{array}$ & $\begin{array}{c}\text { Cumulative } \\
\text { Percent }\end{array}$ \\
\hline Male & 43 & 34,4 & 34,4 & 34,4 \\
Female & 82 & 65,6 & 65,6 & 100,0 \\
Total & 125 & 100,0 & 100,0 & \\
\hline
\end{tabular}

Table 2. Respondent based Age

\begin{tabular}{|c|c|c|c|c|}
\hline Age & Frequency & Percent & $\begin{array}{c}\text { Valid } \\
\text { Percent }\end{array}$ & $\begin{array}{c}\text { Cumulative } \\
\text { Percent }\end{array}$ \\
\hline 18 & 7 & 5,6 & 5,6 & 5,6 \\
19 & 33 & 26,4 & 26,4 & 32,0 \\
20 & 46 & 36,8 & 36,8 & 68,8 \\
21 & 30 & 24,0 & 24,0 & 92,8 \\
22 & 7 & 5,6 & 5,6 & 98,4 \\
23 & 2 & 1,6 & 1,6 & 100,0 \\
Total & 125 & 100,0 & 100,0 & \\
\hline
\end{tabular}

Despite several studies, age does influence behavior and voter perceptions while gender does not actually have any significance as a person's basis choose, but the description of the respondents is presented to show the distribution of the reliability of this study. 
Table 3. Respondent based Residence

\begin{tabular}{|l|c|c|c|c|}
\hline \multicolumn{1}{|c}{$\begin{array}{c}\text { Distribution of } \\
\text { respondents }\end{array}$} & Frequency & Percent & $\begin{array}{c}\text { Valid } \\
\text { Percent }\end{array}$ & $\begin{array}{c}\text { Cumulative } \\
\text { Percent }\end{array}$ \\
\hline Banjarnegara Regency & 1 & 8 & 8 & 8 \\
\hline Blora Regency & 6 & 4,8 & 4,8 & 5,6 \\
\hline Boyolali Regency & 1 & 8 & 8 & 6,4 \\
\hline Demak Regency & 5 & 4,0 & 4,0 & 10,4 \\
\hline Grobogan Regency & 4 & 3,2 & 3,2 & 13,6 \\
\hline Kebumen Regency & 3 & 2,4 & 2,4 & 16,0 \\
\hline Kendal Regency & 6 & 4,8 & 4,8 & 20,8 \\
\hline Klaten Regency & 5 & 4,0 & 4,0 & 24,8 \\
\hline Pekalongan Regency & 1 & 8 & 8 & 25,6 \\
\hline Pemalang Regency & 5 & 4,0 & 4,0 & 29,6 \\
\hline Purbalingga Regency & 4 & 3,2 & 3,2 & 32,8 \\
\hline Purworejo Regency & 2 & 1,6 & 1,6 & 34,4 \\
\hline Rembang Regency & 4 & 3,2 & 3,2 & 37,6 \\
\hline Semarang Regency & 7 & 5,6 & 5,6 & 43,2 \\
\hline Sragen Regency & 1 & 8 & 8 & 44,0 \\
\hline Sukoharjo Regency & 5 & 4,0 & 4,0 & 48,0 \\
\hline Wonogiri Regency & 5 & 4,0 & 4,0 & 52,0 \\
\hline Wonosobo Regency & 4 & 3,2 & 3,2 & 55,2 \\
\hline Pekalongan City & 3 & 2,4 & 2,4 & 57,6 \\
\hline Semarang City & 47 & 37,6 & 37,6 & 95,2 \\
\hline Surakarta City & 6 & 4,8 & 4,8 & 100,0 \\
\hline Total & & 100,0 & 100,0 & \\
\hline & & & & \\
\hline
\end{tabular}

From the distribution of respondents' residences, the data already represents 21 regions that will carry out the Pilkada on December 9, 2020. Most respondents live in the Semarang City Region where in the 2020 Pilkada, the city of Semarang is one of the regions where Regional Head Candidates will fight Box Empty. The city of Semarang, which is the capital of Central Java Province, will be a barometer of the success of the 2020 Pilkada in terms of voter participation later.

\section{Results and Discussion}

In modern political analysis, political participation is an important issue, and recently it has been studied a lot, especially in relation to developing countries. What is political participation? As a general definition, it can be said that political participation is the activity of a person or group of people to participate actively in political life, among others by electing the leadership of the state and, directly or indirectly, influencing government policy (public policy). This activity includes actions such as voting in general elections, attending general 
meetings, holding contact (contacting) or lobbying with government officials or members of parliament, becoming a member of a party or social movement with direct action, and so on. For more details, below are the opinions of several scholars who pioneered participation studies with political parties as the main actors. Herbert Mc Closky, a figure on participation issues, argues: Political participation is the voluntary activities of citizens through which they take part in the process of electing rulers, and directly or indirectly, in the process of forming public policies [3].

In relation to new countries Samuel P. Huntington and Joan M. Nelson in No Easy Choice: Political Participation in Developing Countries provides a broader interpretation by including explicitly illegal acts and violence. Political participation is the activity of citizens who act as individuals, which is intended to influence decision-making by the government. Participation can be individual or collective, organized or spontaneous, steady or sporadic, peaceful or violent, legal or illegal, effective or ineffective [3]. According to Huntington and Nelson [4]in his book "Political Participation in Developing Countries" states that political participation is the activity of individual citizens, the state for influence government decision making.

In democracies it is generally considered that the more public participation, the better. In this mindset, the high level of participation indicates that citizens follow and understand political issues and want to be involved in these activities. It also shows that the regime concerned has a high degree of legitimacy. On the other hand, a low level of participation is generally considered a bad sign, because it can be interpreted that many citizens do not pay attention to state matters. In general, low participation is considered to indicate low legitimacy.

Apart from those who participate in one or more forms of participation, there are members of the community who do not involve themselves in political activities at all. This is the opposite of participation and is called apathy. The question arises: why are people apathetic? There are several answers. They do not participate in elections because they are indifferent and uninterested in, or lack understanding of, political matters. There are also those who do not believe that efforts to influence government policy will succeed, and there are also those who deliberately do not take advantage of the opportunity to vote because they happen to be in an environment where non-participation is common.

There is the possibility that the person may not vote because they think things are not so bad and that whoever gets elected will not change the situation. Thus he did not feel the need to take advantage of his voting rights. So, "apathy" in this view does not refer to feelings of disappointment or frustration, but instead as a manifestation of satisfaction and trust in the existing political system. Therefore, at least in Western democracies, the phenomenon of not voting can be interpreted as reflecting the stability of the political system in question.

According to Surbakti [5] political participation divided into two, namely active participation and passive participation. Active participation is proposing a general policy, put forward general policy alternatives different from the policies made by the government, proposing criticism and improvement to straighten policy, pay taxes and elect government leaders. Instead, activities are included in the category passive participation in the form of activities obey the government, accept, and just implement every government decision [5].

The forms and frequencies of political participation can be used as measures to assess political system stability and satisfaction or discontent citizens of the country. Gabriel A. Almond distinguishes political participation into two forms of action, namely conventional political participation and non-conventional political participation [6] 
Table 4. Almond's Form of Political Participation

\begin{tabular}{|c|c|}
\hline Conventional & $\begin{array}{l}\text { Non Conventional } \\
\end{array}$ \\
\hline $\begin{array}{l}\text { 1. Voting } \\
\text { 2. Political discussion } \\
\text { 3. Campaign activities } \\
\text { 4. Forming and joining interest } \\
\text { groups } \\
\text { 5. Individual communication } \\
\text { with political and } \\
\text { administrative officials }\end{array}$ & $\begin{array}{l}\text { 1. Petitioning } \\
\text { 2. Demonstrate } \\
\text { 3. Confrontation } \\
\text { 4. Strike } \\
\text { 5. Political violence against } \\
\text { property (vandalism, bombing, } \\
\text { arson) } \\
\text { 6. Actions of political violence } \\
\text { against humans (kidnapping, } \\
\text { murder) } \\
\text { 7. Guerrilla war }\end{array}$ \\
\hline
\end{tabular}

Political participation in Pilkada is part of political participation in general. Electoral participation is divided into two categories, namely conventional and non-conventional ones [7]. Conventional electoral participation in Pilkada is closely related to the ownership of citizens' rights as voters. Non-conventional electoral participation is closely related to citizen participation during the Pilkada stages. Citizens must be involved in the Pilkada stages by actively participating in various Pilkada activities. Non-conventional electoral participation can also be carried out actively in various activities of interest groups or volunteer groups in Pilkada. In addition, citizens can also participate in activities outside of the Pilkada stage, such as being active in various activities of interest groups or volunteer groups in Pilkada and activities of pressure groups or NGOs that either support Pilkada candidates or who criticize Pilkada.

The majority of respondents know that in 2020 Pilkada will be held at the national level. However, when asked further, do they know if the area where they live will hold Pilkada?The results showed that $89 \%$ of the students knew which districts / cities would carry out the simultaneous regional elections in 2020 . Only about $11 \%$ did not know which regions would hold the 2020 Pilkada Simultaneously. This condition occurs because the socialization carried out by the Regency/City KPU has not yet been optimal because the implementation of the Pilkada is still 7 months away when this research is carried out.

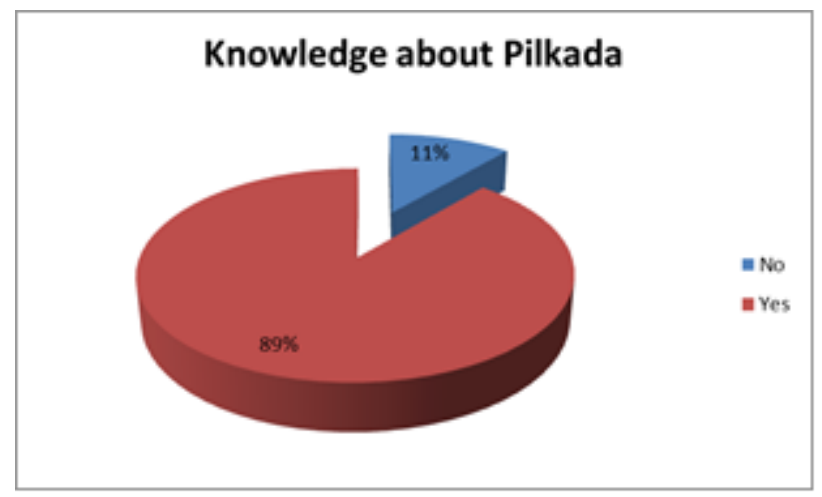

Diagram 1. Student Knowledge about Pilkada in Central Java. 
However, the students' enthusiasm in following the news on the simultaneous regional elections was not optimal. This could be because the information on the Pilkada itself is not very well uploaded by the print media because it is behind the trends in reporting with the Covid-19 outbreak that has occurred in Indonesia and the world. Or students also don't think too much about political news in the midst of the Covid-19 Pandemic. The data shows that around $39 \%$ of students do not intensively follow the news of the simultaneous regional elections in various media.

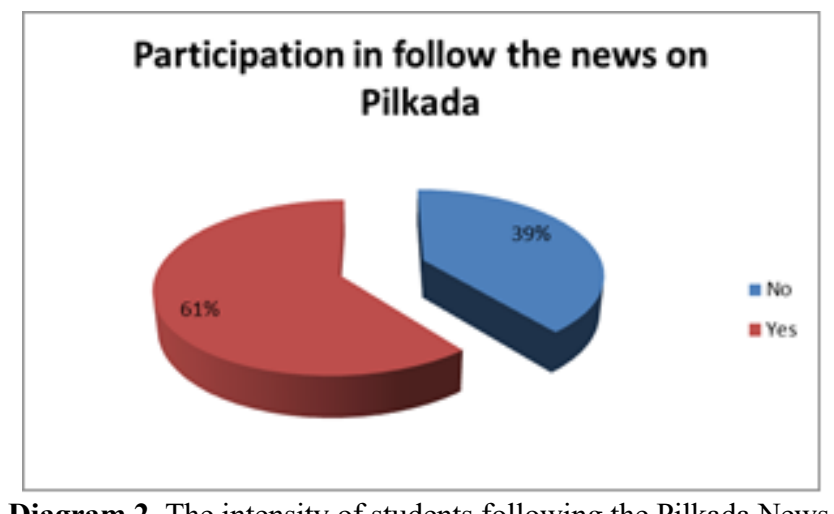

Diagram 2. The intensity of students following the Pilkada News.

The findings from the survey results show that the enthusiasm of students to be involved in the election committee is very low. Only $14 \%$ of students expressed a willingness to become a Simultaneous Pilkada Committee, while $86 \%$ of students were not interested in becoming a Simultaneous Pilkada 2020 committee.

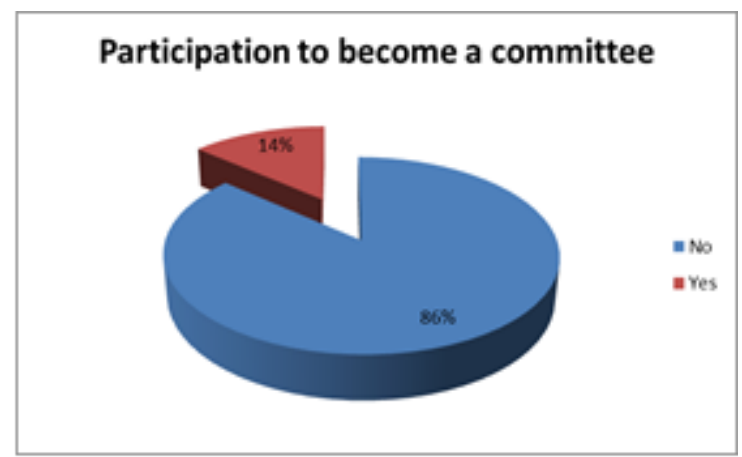

Diagram 3. The desire to become a committee.

Likewise, student participation in the Pilkada Campaign is still low. The majority of students, $62 \%$, stated that they would not participate in the campaign. This is actually quite worrying, because through the Campaign, students will be able to find out the quality of the Candidate Pairs who are advancing in the 2020 Pilkada Simultaneously. Only about $38 \%$ of students stated that they would participate in the implementation of the 2020 Simultaneous Pilkada Campaign. 


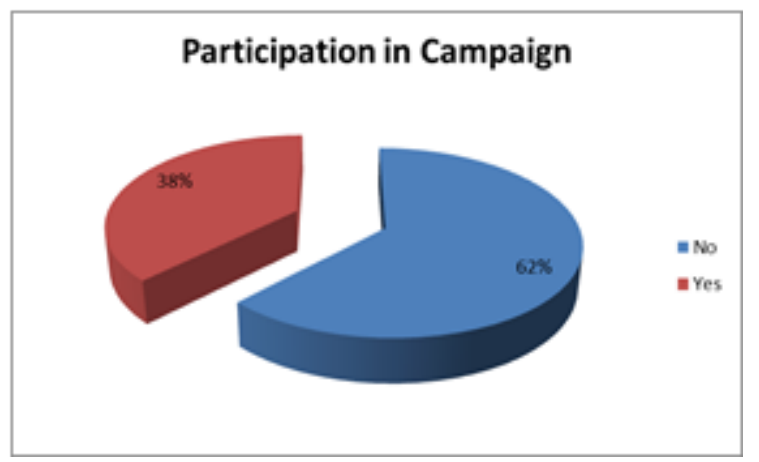

Diagram 4. Participation in Campaigns.

Although the majority of students stated that they did not want to participate in the Committee or participate in the 2020 Pilkada campaign, almost $96 \%$ of students stated that they would use their voting rights in the 2020 Pilkada Simultaneously. There are several possibilities for this, because the average student only has 1 experience participating in the General Election, but has never participated in the Pilkada Simultaneously. This is what encourages students to vote in the Pilkada Simultaneously. Only about $1,6 \%$ of students stated that they would not use their voting rights in the 2020 simultaneous regional elections in Central Java and There are 2.4 percent of respondents who are still hesitant to use their voting rights in the Pilkada.

However, there were still quite a large number of students who said they did not want to follow the vote count, namely $45,4 \%$. This shows that students still perceive political participation as only an activity to use voting rights in the 2020 Pilkada Simultaneously. This condition is the discussion of the team to provide material that can increase student participation not only to cast votes, but also to be involved in other political activities.

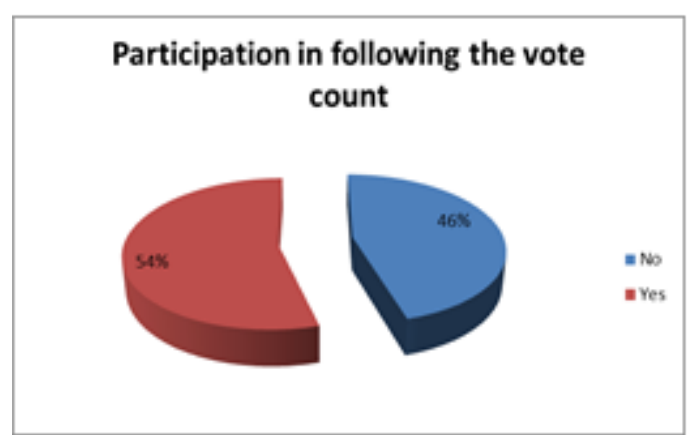

Diagram 5. Participation in vote counting.

Similar results occurred when students were asked to participate in the 2020 Regional Election Supervision in Central Java. About $60,8 \%$ of students stated that they wanted to supervise the 2020 Pilkada Simultaneous process in Central Java so that it could be held based on the principles of direct, general, free, confidential, honest and fair. There are about 39,2\% of students stated that they are not interested in participating in the supervision of the 2020 Simultaneous Regional Elections in Central Java. 
Is participation level important, and if so, how and why? For some, high levels of participation are intrinsically a "good" that maximizes inclusiveness, a key conceptual element of democracy. For others, high turnout should be valued or disrespected because of the consequences, with normative principles that are still much debated. From the evidence showing that many people know very little about politics, some conclude that people's votes uninformed people about politics are worthless, and democratic processes might be better off without it. Repeated survey research shows a low level of ideological consistency among many citizens as the time leading up to the election passes. A high level of knowledge does not guarantee a well-considered option. Given this, there is a reason to judge everyone's preferences: the more that count, the more likely the collective choice will be better for everyone. The debate about whether or not we should judge the maximum or minimum number of participation votes "quality" in normative hearts, and cannot be resolved by empirical analysis. However, empirical research can attempt to uncover the consequences of different participation- differences on which some judgments can be made. In the United States and elsewhere, those who are less likely to vote are found among the young, those with low incomes, and those with low levels of education. Therefore, one might expect less governmental concern for the young, the poor, and those less educated, among whom low participation rates are centralized [8].

This classic indicator of popular participation is generally understood to be an important dimension of the quality of democracy. It has also been used as an indirect measure of popular legitimacy in many classical studies of established democracy. Although context is likely to make a difference, A higher turnout is preferable from the point of view of the quality of democracy as a realization equal political participation. People are supposed to rule over themselves through the election of leaders in elections, therefore, the greater the share of voters who actually show up for voting, the more popular power actualized [9].

\section{Conclusion}

A student University of Diponegoro has participation high enough politics in using Suffrage / Right to vote in the local elections in 2020 in Central Java Unison. However, the participation of students in other political activities still needs to be increased including the desire to follow the news about the Simultaneous Regional Election, participation in the committee, participation in the campaign, participation in the vote count and participation in the supervision of the 2020 Pilkada Simultaneously in Central Java.

For this reason, the KPUD as the organization that organizes the 2020 Pilkada Simultaneously in Central Java must strive to socialize the stages of the Pilkada, so that community participation, especially students, is quite high and participation does not only vote on election day.

\section{References}

[1] S. Pamungkas, Perihal Pemilu. Yogyakarta: Laboratorium Ilmu Pemerintahan Fisipol UGM, 2009.

[2] U. Qodarsasi and N. R. Dewi, "Perilaku Partisipasi Pemilih pada Pemilihan Kepala Daerah Kabupaten Kudus Tahun 2018," JSW (Jurnal Sosiol. Walisongo), vol. 2, no. 2, pp. 169-188, 2018

[3] M. Budiardjo, Dasar-dasar Ilmu Politik. Jakarta: PT Gramedia Pustaka Utama, 2010. 
[4] P. Samuel, "Huntington. Gelombang Demokratisasi ketiga," Jakarta. Graf., 1997.

[5] R. Subakti, Memahami Ilmu Politik. 2007.

[6] S. Gatara, Ilmu Politik. Bandung : Pustaka Setia. .

[7] C. Sutrisno, "Partisipasi Warga Negara Dalam Pilkada," JPK (Jurnal Pancasila dan Kewarganegaraan), vol. 2, no. 2, pp. 36-48, 2017.

[8] J. Fisher, E. Fieldhouse, M. N. Franklin, R. Gibson, M. Cantijoch, and C. Wlezien, The Routledge handbook of elections, voting behavior and public opinion. Routledge, 2017.

[9] S. I. Lindberg, "The democratic qualities of competitive elections: participation, competition and legitimacy in Africa," Commonw. Comp. Polit., vol. 42, no. 1, pp. 61-105, 2004. 